\title{
Princip trvale udržitelného rozvoje v sociálním učení církve
}

\author{
Miroslav Kněz, Roman Míčka
}

\begin{abstract}
"Nenaučíme-li se energicky omezovat své potřeby a nároky, podřizovat své zájmy morálním imperativưm, podlehneme jako lidský rod záhubě. Neorientuje-li se osobnost na hodnoty vyšši, než je vlastni egoistické já, převládne v ní nevyhnutelně zkaženost a úpadek."

Alexandr Solženicyn

"Jak jsem se již zminil dř́ve, bylo tu takzvané křest'anství... Etika a filosofie nedostatečné spotreby..."

Aldous Huxley, Brave New World, 1932
\end{abstract}

\begin{abstract}
"Způsob, jak lidstvo zachází s životním prostředim, je ovlivněn tím, jak zachází samo se sebou, a naopak. To vybizí dnešní společnost k serióznímu přehodnoceni svého životního stylu, jenž $v$ mnoha částech světa inklinuje k hedonismu a konzumismu, bez ohledu na škody, jaké z toho plynou. Nezbytná je skutečná změna myšleni, která povede k prijetí nových způsobů..."

Caritas in veritate, čl. 51
\end{abstract}

Trvale udržitelná lidská činnost člověka v interakci s prírodním prostředím a přirodními procesy je závažným tématem a otázkou kladenou v oblasti ekologické, ekonomické i politické. $\vee$ tomto článku se pokusíme - po stručném nastínění vývoje, obsahu a debat - hledat možné souvislosti a prípadný soulad pojmu trvale udržitelného rozvoje (dále jen TUR) s tzv. sociálním Učením katolické církve (dále jen SUC). SUC (angl. the Social Doctrine of the Church, Catholic social doctrine, lat. Ecclesiae doctrina socialis), vyjádřené obvykle v oficiálních církevních dokumentech, se vyslovuje k aktuálním politickým, ekonomickým a sociálním otázkám. Není ovšem prímo politickým programem či konkrétním návodem k realizaci politiky, ale vyjádřením „hlubokého zamyšlení ve světle víry a církevní tradice nad složitou skutečností lidské existence ve společnosti a v mezinárodním kontextu".' SUC ve svém jádru obsahuje vyjádření podstatných křesfanských hodnot a pravd o člověku, které se pokouší aplikovat na společenské poměry, a tím vstupuje "do dialogu s rưznými disciplínami, které se člověkem zabývají, sjednocuje jejich přispěvky a pomáhá jim otevřít se $\vee$ širším horizontu službě člověku, poznanému a milovanému $\vee$ plné širi jeho poslání"2. $\vee$ oblasti hodnocení politických a ekonomických skutečností si nenárokuje, jak již bylo výše zmíněno, výlučnost či neomylnost, priznává i určitou „experimentální dimenzi“3 a legitimitu plurality pohledů a strategií na realizaci hodnot prosazovaných SUC. ${ }^{4}$ Ekologická dimenze nebyla zpočátkU v SUC príliš patrná, ale v současnosti se stává jedním z jejích podstatných aspektů.

\footnotetext{
1 Sollicitudo rei socialis, čl. 41.

2 Centesimus annus, čl. 59.

3 Tamtéž, čl. 43.

4 Srov. Gaudium et spes, čl. 50.
} 


\section{Vývoj pojmu TUR}

O udržitelném rozvoji můžeme najít zmínky již v devatenáctém století. ${ }^{5}$ Současný obsah pojmu se však začíná odvíjet až od sedmdesátých let minulého století, kdy Římský klub ${ }^{6} \mathrm{v}$ roce 1972 inicioval vydání vědecké studie nesoucí název Meze růstu (angl. Limits of Growth). Tato studie poukazuje na neudržitelnost hospodářského růstu v budoucnu, kdy překročí svou udržitelnou mez. Jako východisko z této nepříznivé prognózy se nabízí jeho omezení či úplné zastavení. Vývoj nastíněných předpovědí potvrzuje v roce 1992 další studie Překročení mezí (angl. Beyond the Limits). ${ }^{7}$ Udržitelností se ve stejné době začínají zabývat také konference OSN věnované životnímu prostředí. Právo na životní prostředí považuje za jedno ze základních lidských práv první z nich, konaná ve Stockholmu v roce 1972. V roce 1980 vypracovaly tři světové organizace (Mezinárodní svaz na ochranu př́rody - IUCIN, Program OSN na ochranu životního prostředí - UNEP a Světový fond na ochranu přírody - WWF) dokument Světová strategie ochrany životního prostředí (WSC). Jde o první oficiální dokument akceptující pojem TUR. V roce 1983 OSN ustanovuje komisi (World Commission on Environnement and Development), která měla předložit návrhy strategií zajištujujících trvalou udržitelnost rozvoje. Ta vydává v roce 1987 svůj návrh v podobě dokumentu Naše společná budoucnost (dokument Our Common Future je také znám jako tzv. Brundtland report ${ }^{8}$ ), v němž se objevila první definice rozvoje respektujícího princip trvalé udržitelnosti: „....trvale udržitelný rozvoj znamená zajištění potřeb současných generací, aniž by bylo ohroženo zajištění potřeb generací příštích... ${ }^{~}$

Od této doby se trvale udržitelný rozvoj stává dlouhodobou integrální koncepcí, která klade zásadní důraz na provázanost ekonomických, ekologických a sociálních faktorů. Značný posun od obecné ke konkrétnější strategii nabízí druhá z konferencí, konající se v roce 1992 v Rio de Janeiru a zaměřená na životní prostředí a rozvoj. Tento summit mimo jiné přijímá Deklaraci (27 zásad TUR) a dokument zvaný Agenda 21 (o přechodu k TUR), jejichž cílem je realizace souladu hospodářského a sociálního rozvoje s účinnou ochranou životního prostředí. Téhož roku vzniká Komise OSN pro TUR (United Nations Commission on Sustainable Development CSD), která má reflektovat plnění Agendy 21. Následuje tzv. „Summit milénia“ v roce 2000, kde jsou formulovány cíle s ohledem na trvalou udržitelnost do roku 2015. Třetí konference OSN o TUR se konala v Johannesburgu v roce 2002. Přestože je oproti minulým počinům konkrétnější svým obsahem, ${ }^{10}$ ve svých výstupech (Johannesburgská deklarace a Implementační plán) zůstává pouze v obecné rovině morálního apelu na jednotlivé státy. Konkrétní opatř̌ení ohledně udržitelného hospodaření s přírodními zdroji však její závěry nenabízí. ${ }^{11}$

Mohli bychom se zabývat implementací principů TUR do legislativy EU či konkrétních států. ${ }^{12}$ Ta je vztažena pouze na lokální kontinent či stát, neřeší však problém v globálním měřítku, protože zvažuje pouze zájmy dané oblasti, jejíž udržitelnost nemusí vždy sledovat vývoj

5 Např. Thomas R. Malthus se svým chápáním udržitelnosti jako principu udržujícího rovnováhu mezi minimální mzdou a produkcí. Hlavním kritériem udržitelnosti je zde počet obyvatel, jenž je i samotným limitem neudržitelného růstu.

6 Nadnárodní výzkumný institut založený v roce 1968, jehož cílem je posuzovat dopady vládní i nevládní politiky na veřejný život.

7 Karel TOMŠÍK, Evropská integrace a environmentální ekonomika, Praha: Česká zemědělská univerzita, 2009, s. 96.

8 Gro H. BRUNDTLANDOVÁ a kol., Naše společná budoucnost, Praha: Academia, 1991, s. 43.

9 () UN Resolution A/RES/42/187. Report of the WCED /1987/ (on-line), dostupné na: http://www.un-documents.net/a42r187.htm, citováno dne 21. 8. 2014. (Orig.: ,....sustainable development, which implies meeting the needs of the present without compromising the ability of future generations to meet their own needs...")

10 Tématy jsou: globalizace, chudoba a miléniové cíle rozvoje, model spotřeby a výroby, ochrana biodiverzity a přírodních zdrojů, harmonizace rozvoje a životního prostředí.

11 Srov. Karel TOMŠÍK, Evropská integrace a environmentální ekonomika, s. 100-101.

12 Např. v ČR podle § 6 zákona č. 17/1992 Sb., o životním prostředí, je: „Trvale udržitelný rozvoj společnosti takový rozvoj, který současným i budoucím generacím zachovává možnost uspokojovat jejich základní životní potřeby a přitom nesnižuje rozmanitost př́rody a zachovává přirozené funkce ekosystémů." Srov. Zákon č. 17/1992 Sb., o životním prostředí, ve znění pozdějších předpisů (on-line), dostupné na: http:// goo.gl/2d1AzA, citováno dne 21. 8. 2014. 


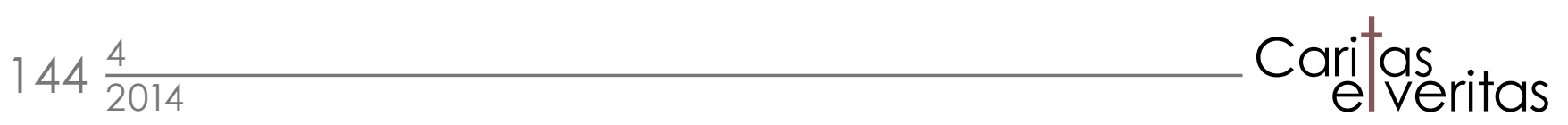

v ostatních zemích. Další celoplanetární summit, který by se týkal dalšího rozvoje a implementace TUR, se teprve očekává.

K tomu s ohledem na výše i níže referované dodejme, že debata vedená na poli rozvoje, ekologie a ekoetiky je velice barvitá a spletitá. I když existuje základní shoda na nezbytnosti ochrany životního prostředí a jejího uchování pro budoucí generace lidstva, stále panují zásadní rozpory ohledně politických forem řešení, nezbytných priorit, míry naléhavosti jednotlivých problémů i možností umenšení civilizačních nároků a lidské spotřeby. Z několik desetiletí trvající ekologické debaty je na jednu stranu zřejmé, že skeptické prognózy ohledně možností vývoje, limitů a vyčerpání zdrojů se často neprokázaly a byly nepřiměřeně pesimistické, na straně druhé i při velké nejistotě budoucích prognóz existuje široká shoda na potřebě praktické aplikace principu odpovědnosti. Slovy Hanse Jonase: „Proroctví zkázy je třeba naslouchat více než proroctví zdaru. "13 Princip předběžné opatrnosti by se však zároveň neměl stát legitimizačním nástrojem $\mathrm{k}$ zablokování přiměřeného integrálního růstu a $\mathrm{k}$ vyvolávání nepřiměřených a apokalyptických obav. Navzdory katastrofickým předpovědím ohledně vyčerpání zdrojů a přelidnění se ukazuje, že obavy byly a jsou často nepřiměřené, je však zřejmé, že civilizační blahobyt vybudovaný $\mathrm{v}$ kontextu západní civilizace není aplikovatelný v globálním měřítku a že je třeba v brzké perspektivě volit umírněnější a šetrnější životní styl, na což není mentalita a mravní zralost vyspělejších, ale ani rozvojových společností dosud připravena.

\section{Rozvoj a "udržitelný rozvoj" v SUC}

Pojem rozvoje je samozřejmě v dokumentech SUC hojně zastoupen, na prvním místě jde však ve starších dokumentech obvykle o ekonomický, politický, technický a vědecký rozvoj - ekologická dimenze rozvoje není výrazněji akcentována. Ekologický rozměr činnosti člověka je plněji př́tomen v SUC až od éry pontifikátu Jana Pavla II. Teprve encyklika Caritas in veritate (2009) Benedikta XVI. však skutečně komplexně pojednává o vztahu ekonomické a ekologické dimenze rozvoje.

V původním latinském znění dokumentů jsou používány různé pojmy překládané do češtiny jako pokrok či rozvoj (lat. progressus, profectum, incrementum). Jako příklad za mnohé můžeme uvést i jednu z klasických definic tzv. personálního principu, který je považován za nejvyšší zásadu celého SUC vůbec: ${ }^{14}$

„Ze společenské povahy člověka je zřejmé, že pokrok lidské osoby a rozvoj společnosti na sobě vzájemně závisí. Vždyt’ lidská osoba je a musí být počátkem, nositelem i cílem všech společenských institucí, nebot' má přirozenou potřebu žít společensky. "15

Z uvedené definice je zřejmé, že rozvoj a pokrok je považován za podstatný aspekt člověka a společnosti, přičemž má směřovat $k$ lidské osobě jakožto cíli veškerého politického a ekonomického snažení. Jak koncilní konstituce Gaudium et spes, tak i ostatní dobové dokumenty SUC chápou přírodu jako výhradně (převážně) podřízenou cílům lidského úsilí, hovoří se zde o postupujícím trendu upevňování vlády nad přírodou pomocí vědy a techniky. ${ }^{16}$ Navzdory již

13 Hans JONAS, Princip odpovědnosti: Pokus o etiku pro technologickou civilizaci, Praha: OIKOYMENH, 1997, s. 62.

14 Srov. Mater et magistra, čl. 219-220.

15 Gaudium et spes, čl. 25.

16 Srov. tamtéž, čl. 9, 33. 
tehdy často vyjadřovaným obavám před možným přelidněním a nedostatkem či vyčerpáním zdrojů SUC tlumí takové znepokojení a vyjadřuje optimismus:

„Hledíme-li však na poměr mezi růstem obyvatelstva a možnostmi jeho výživy ze světového hlediska, nezdá se, že by v dnešní době nebo v blízké budoucnosti musel působit vážné nesnáze. Důvody pro opačné tvrzení jsou ještě př́liš nejisté a pochybné, než aby z nich bylo možno vyvozovat něco určitého. Nadto vložil Bůh ve své dobrotě a moudrosti do př́rody téměř nevyčerpatelné možnosti a lidem dal tolik duševních schopností, že mohou s pomocí vhodných nástrojů využít těchto přirodních darů $\mathrm{k}$ uspokojení svých životních potřeb... Ostatně dosud dosažené úspěchy vědy a techniky nás opravňují $\mathrm{k}$ téměř neomezeným nadějím do budoucna. ${ }^{117}$

Z obsahu encyklik je zřejmé, že akcentují zejména dynamický ekonomický rozvoj, který by ve svých důsledcích znamenal eliminaci chudoby a nedůstojných podmínek lidského života ve světě, zejména v chudých a rozvojových zemích. Nejvíce tento rozměr akcentuje encyklika „O rozvoji národů“ Populorum progressio (1967):

„Rozvoj národů sleduje církev pozorně, především těch, které se chtějí vymanit z hladu, bídy, endemických nemocí, nevzdělanosti; národů, které hledají bohatší účast na vymoženostech civilizace a dožadují se, aby jejich nadání došlo v civilizačním procesu většího ocenění; národů, které vytrvale usilují o svůj všestranný rozvoj.“"18

Encyklika ovšem explicitněji hovoří o všestranném rozvoji člověka (lat. homo plene excolatur), ${ }^{19}$ či dokonce o integrálním rozvoji člověka a lidstva: „Rozvoj, o kterém mluvíme, se neomezuje na pouhý hospodářský růst. Aby byl opravdový, musí být všestranný (lat. integra), to jest musí vést $k$ rozvoji celého člověka a celého lidstva. “ ${ }^{20}$ Papež Pavel VI. míní kromě ekonomického rozměru i další dimenze lidské existence, zejména náboženskou, kulturní a etickou. I když encyklika Populorum progressio více akcentovala potřebu rozvoje, který není orientován výhradně na ekonomickou dimenzi, ekologický aspekt zde ještě není přítomen. Oproti předchozí zmiňované encyklice však už nehovoří o "nevyčerpatelných“ možnostech přírody, hovoří o tom, že „přírodní bohatství se ztenčuje“, ale jádro problémů spatřuje spíše „V uvolnění bratrských svazků jak mezi jednotlivci, tak mezi národy. “21

Apoštolský list papeže Pavla VI. Octogesima adveniens (1971) je již kritičtější k ideálům pokroku, stálého ekonomického růstu a konzumu, přičemž proti redukci rozvoje na jeho ekonomickou dimenzi staví „pravý pokrok v rozvoji mravního vědomí. Civilizace podle něj vložila př́liš nadějí "do nepřetržitého a neomezeného pokroku bez dohledného konce“ a staví kvantitu na úkor kvality. ${ }^{22}$ Již také explicitně zmiňuje ekologickou tématiku a neutěšené trendy ve vztahu člověka a přírody, dokonce hovoří o „vykořistování" a "hanobení př́rody:

„Zatímco se takto mění obzor člověka již podle obrazů, jaké jsou mu vybírány a předváděny, je možno pocitovat ještě jinou přeměnu, jež je právě tak dramatickým jako neočekávaným důsledkem lidské činnosti. Lidé si náhle uvědomuji: Neuváženým vykořistóováním přrírody riskují, že ji zničí a že se sami stanou obětí tohoto hanobení. Ale nejen životní prostředí se stá-

\footnotetext{
17 Mater et magistra, čl. 188-189.

18 Populorum progressio, čl. 1.

19 Srov. tamtéž, čl. 5.

20 Tamtéž, čl. 14.

21 Obojí tamtéž, čl. 66.

22 Vše Octogesima adveniens, čl. 41
} 


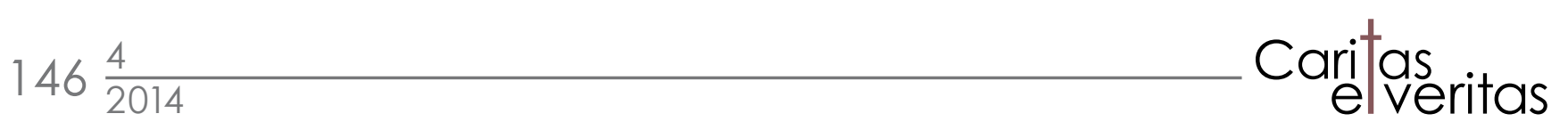

le zhoršuje (znečištění a odpady, nové nemoci, absolutní ničivá síla); ani lidské společenství již člověk neovládá, a tak si může vytvořit pro zítřek životní podmínky, které pro něj budou naprosto nesnesitelné. Jde o rozsáhlý společenský problém, který se týká celé lidské rodiny. K těmto novým výhledům musí křest'ané obrátit pozornost, aby spolu s ostatními lidmi převzali odpovědnost za osud, od nynějška společný. " 23

S érou Jana Pavla II. (1978-2005), ostatně souběžně s obecným rostoucím vzestupem ekologického vědomí, přichází i větší důraz na ekologické otázky a ekologický rozměr rozvoje člověka a lidstva. Papež v roce 1979 vyhlašuje sv. Františka z Assisi patronem ekologů. Papež klade ekologické důrazy ve všech svých sociálních encyklikách, jak v Laborem exercens (1981), kde pointuje teologický rozměr vztahu člověka a přírody, tak v Solicitudo rei socialis (1987), kde dále rozvijí a obohacuje pojem integrálního rozvoje z encykliky Populorum progressio. Zde v kontextu dvacetiletého odstupu a situace Studené války mírní optimismus ve věci rozvoje ${ }^{24}$ kritizuje již ale i fenomén nadměrného rozvoje a konzumismu ${ }^{25}$ a ekologické myšlení spojené s rozvojem považuje za znamení doby:

„Mezi kladnými známkami současné doby sluší také zaznamenat rostoucí vědomí o omezenosti dostupných zdrojů, o potřebě respektování celistvosti a rytmů př́rody a vědomí, že je nutné brát na ně ohled při plánování rozvoje a neobětovat je demagogickým koncepcím. V tom je podstata péče o ekologii." ${ }^{26}$

Ekologickými důrazy prosluly i jiné papežovy dokumenty, kupříkladu Poselství k Světovému dni míru z roku 1990, nazvané Mír s Bohem Stvořitelem, mír s veškerým stvořením, kde volá po formování „ekologického svědomi“", pranýřuje i konkrétní aspekty poškozování př́rody a volá po vložení nového lidského práva "na bezpečnost v životním prostředí“ (angl. right to a safe environment) do Charty lidských práv. Podstatné aspekty tématu jsou sdruženy v poslední papežově sociální encyklice Centesimus annus (1991), kde hovoří o tom, že dřívější stadia lidského rozvoje byla spojena zejména s otázkami nouze a uspokojování základních nezbytných potřeb člověka. Dynamika rozvoje však přinesla nové otázky a nová nebezpečí, zejména ,jev konzumismu“, který se jednostranně obrací k pudové stránce člověka a nerozlišuje skutečné potřeby od umělých a zbytných. ${ }^{27}$ Za otázku těsně související s konzumismem je pak považována otázka ekologie: „Člověk, který je více v zajetí touhy po majetku a po požitku než po bytí a rozvoji, nemírně nedisciplinovaným způsobem spotřebovává zdroje země i zemi samu. “28 Za ještě závažnější než otázky ekologické považuje však papež otázky morálního charakteru, přičemž míní zejména otázku praktického i ideologického rozkladu přirozené rodiny, potratů, euthanasie, homosexualismu a jiných fenoménů tzv. „kultury smrti“:

„Kromě nesmyslného ničení přírodního životního prostředí je nutno zmínit se o ještě závažnějším ničení mravního prostředí; nevěnujeme mu ještě zdaleka potřebnou pozornost. Zatímco se oprávněně, i když mnohem méně než by bylo třeba, snažíme chránit životní podmínky ohrožených živočišných druhů, protože si uvědomujeme, že každý z nich svým dílem přispívá k všeobecné rovnováze na zemi, angažujeme se mnohem méně pro zachování morálních podmínek věrohodné ,humánní ekologie'. Nejen zemi dal Bůh člověku, aby ji užíval s přihlédnutím

\footnotetext{
23 Tamtéž, čl. 21.

24 Srov. Solicitudo rei socialis, čl. 12.

25 Srov. tamtéž, čl. 28.

26 Tamtéž, čl. 26.

27 Srov. Centesimus annus, čl. 36.

28 Tamtéž, čl. 37.
} 
k původnímu cíli tohoto statku, který mu byl darován. Bůh dal člověku také jeho samého, a proto musí člověk respektovat přirozené a morální struktury, jimiž byl vybaven." ${ }^{29}$

V méně formálních projevech a textech Jana Pavla II., než jsou hluboce promyšlené a vyvážené celocírkevní dokumenty, papež často užívá velice silnou a barvitou rétoriku, která nenechá nikoho na pochybách ohledně vážné recepce ekologické otázky. Příkladem je úryvek projevu při generální audienci ze 17. 1. 2001:

„Pokud pohlížíme na krajiny naší planety, bezprostředně si uvědomíme, že lidstvo zklamalo Boží očekávání. Člověk, zejména v naší době, bez váhání zdevastoval zalesněné pláně a údolí, znečistil vody, deformoval prostředí Země, učinil vzduch nedýchatelným, rozvrátil hydrogeologické a atmosférické systémy, obrátil bujně rostoucí oblasti v poušt' a zavedl nekontrolované formy industrializace, degradoval tento ,květinový záhon' - abych použil obraz Dante Alighieriho (Paradiso, XXII, 151) - kterým je Země, náš př́ibytek. Musíme proto povzbudit a podpořit ,ekologickou konverzi', která během minulých desetiletí učinila lidstvo citlivějším vůči katastrofě, které čelí. Člověk již není Stvořitelovým ,správcem', ale svévolným despotou, který nakonec začíná chápat, že se musí zastavit na okraji propasti.“30

Benedikt XVI. (2005-2013) na Jana Pavla II. navazuje, přičemž k zásadnímu a komplexnímu rozpracování tématiky dochází zejména v encyklice Caritas in veritate (2009), která je ostatně věnována právě čtyřicátému výročí encykliky Populorum progressio. Zde papež rozvíjí pojem integrálního rozvoje již ve všech ohledech a v kontextu aktuální situace i ideologických sporů, a to včetně dimenze ekologické, která je zde pojednána nejkomplexněji. Encyklika má klíčový pojem integrálního rozvoje již ve svém podtitulu O integrálním lidském rozvoji v lásce a pravdě (lat. De humana integra progressione in caritate veritateque). Benedikt XVI. Pavla VI. velice chválí pro podněty, které dal pojmu integrálního rozvoje, přičemž je dále kontextualizuje, obohacuje ${ }^{31}$ a zejména zasazuje do kontextu uvažování o lásce (lat. caritas), která je „hlavní hnací silou pravého rozvoje každé lidské osoby i celého lidstva“, ${ }^{32}$ zároveň je láska v pravdě (lat. caritas in veritate) princip, od něhož se odvíjí celé SUC. ${ }^{33}$ Pokud jde přímo o recepci klíčového pojmu TUR, tedy sustainable development, ten můžeme v zásadě přímo nalézt v čl. 21, kde se hovoří o tom, že ekonomický rozvoj, který má produkovat reálný růst a být prospěšný všem, je vpravdě trvale udržitelný (angl. sustainable, lat. sustinendum). Přímé spojení „udržitelný rozvoj", respektive "pravý udržitelný rozvoj", je ve 4. pádě (lat. veram sustinendam progressionem) užit v čl. 65 encykliky Caritas in veritate, ovšem tento pojem je v anglické verzi přeložen jako „sustaining true development“ a ve verzi české jako „opravdový rozvoj“. Ekologická dimenze rozvoje je akcentována zejména v článcích 48-52, kde jsou kromě rekapitulované teologické dimenze zdůrazněny i aspekty energetické problematiky, užívání neobnovitelných zdrojůo, energetické náročnosti a ochrany klimatu. Zároveň je však potřeba vnímat i polemický tón, který papež vede vůči některým ekologickým konceptům „neantropocentrického“ charakteru:

„Je však třeba zdưraznit i to, že je v rozporu s opravdovým rozvojem, jestliže se přríroda pokládá za něco důležitějšího, než je lidská osoba. Takový př́ístup ústí do novopohanských postojů nebo do nového panteismu. ${ }^{\text {334 }}$

\footnotetext{
29 Tamtéž, čl. 38.

30 Jan Pavel II., Generální audience (17. 1. 2001), čl. 3-4.

31 Srov. Caritas in veritate, čl. 21.

32 Tamtéž, čl. 1.

33 Tamtéž, čl. 6.

34 Tamtéž, čl. 48.
} 


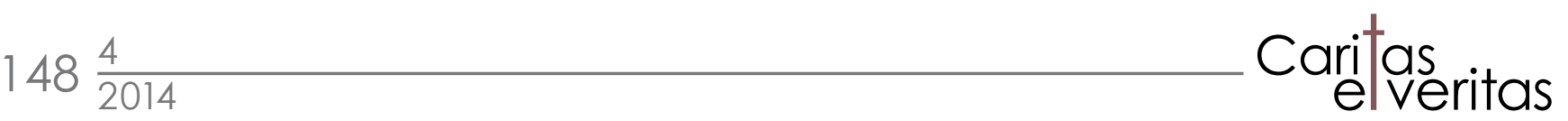

Papež klade důraz na primát lidské osoby v otázkách rozvoje a ekologie, který nesmí mít technokratický, ale ani biocentrický či ekocentrický ráz, kritizuje tedy i radikální ekologismus a romantické představy a ideologie o povaze přírody:

„Negativní ideologie bohužel neustále vzkvétají... V současnosti vidíme na jedné straně snahy svěřit celý proces rozvoje pouze technice. Na druhé straně jsme svědky zrodu ideologií, které užitečnost rozvoje naprosto popírají: rozvoj je považován ve své podstatě za nelidský, přinášející pouhý úpadek. “35

Zdůrazňuje naopak důležitost kulturní, institucionální a morální, nikoli materiální povahy kvality i kvantity rozvoje. ${ }^{36}$ Zdůrazňuje odpovědnou svobodu oproti technokratickým řešením $^{37}$ a před často neefektivní rozvojovou pomocí preferuje zapojení chudých zemí do globálních tržních procesů (kritika celních sazeb). ${ }^{38}$ Zároveň volá po revizi životního způsobu zejména rozvinutých zemí („Způsob, jak lidstvo zachází s životním prostředím, je ovlivněn tím, jak zachází samo se sebou, a naopak. To vybízí dnešní společnost k serióznímu přehodnocení svého životního stylu, jenž v mnoha částech světa inklinuje k hedonismu a konzumismu, bez ohledu na škody, jaké z toho plynou. Nezbytná je skutečná změna myšlení, která povede k přijetí nových způsobů...“ ${ }^{39}$ ), přičemž neváhá zdůraznit neschopnost bohatých zemí již „,rozeznat, co je lidské,“ a kritizovat, stejně jako papež Jan Pavel II., struktury „kultury smrti“:

„Nelze podceňovat znepokojující scénáře budoucnosti člověka a nové mocné nástroje, jež má k dispozici ,kultura smrti'. K tragické a velmi rozšířené ráně potratů lze do budoucna přidat - ale zaobaleně to in nuce existuje už dnes - systematické eugenické plánování porodnosti. $\mathrm{V}$ opačném směru se prosazuje mens euthanasica... Za těmito scénáři stojí kulturní postoje, které popírají lidskou důstojnost. “40

Poselstvím k Světovému dni míru z roku 2010 s podtitulem Chcešli být tvưrcem míru, ochraňuj stvoření papež Benedikt dále rozvíjí a aktualizuje některé aspekty ekologie - hovoří o potřebě provést "hlubokou a prozíravou revizi rozvojového modelu“, volá po "hluboké kulturní obnově“ lidstva a znovuobjevení hodnot utvářejících pevný základ prevence krize v oblasti „ekonomické, potravinové, ekologické nebo sociální““ ${ }^{41} \mathrm{~V}$ oblasti směřující k perspektivně udržitelnému rozvoji hovoří o mezigenerační solidaritě („Potřeba dospět k čestné mezigenerační solidaritě se jeví jako naléhavá. Náklady spojené s využíváním společných přírodních zdrojů nemohou zatěžovat přiští generace. “ ${ }^{42}$ ) a v podstatě recipuje i často zdůrazňovanou otázku zohledňování tzv. externalit („Při využívání přírodních zdrojů je třeba se také starat o jejich ochranu a plánovat i její náklady - ekologické i sociální - a započítávat je jako neodmyslitelnou položku vlastních nákladi̊ na hospodářskou činnost. ${ }^{“ 33}$ ).

Papež František (2013-dosud) prozatím dané otázky výrazněji nad rámec předchozích papežů nerozvinul, i když s ohledem na jím zvolené jméno i ekologické důrazy v dosavadních projevech lze očekávat jejich další prohlubování. Co se týče pojmu udržitelného rozvoje, ten papež přímo zmiňuje ve své exhortaci Evangelii gaudium (2013), kde říká, že „podmínky udržitelného

\footnotetext{
35 Tamtéž, čl. 14.

36 Srov. tamtéž, čl. 19 a 22.

37 Srov. tamtéž, čl. 17.

38 Srov. tamtéž, čl. 33 a 58.

39 Tamtéž, čl. 51.

40 Tamtéž, čl. 75.

41 Vše srov. BENEDIKT XVI., Poselstuí k Světovému dni míru (2010), čl. 5.

42 Tamtéž, čl. 8.

43 Tamtéž, čl. 7.
} 
a mírumilovného rozvoje (angl. sustainable and peaceful development) se dosud adekvátně neujaly a nerealizovaly “, ${ }^{44}$ ovšem nijak nově jej neinterpretuje. Již od ledna 2014 je však v médiích avizováno, ${ }^{45}$ že papež František má záměr napsat a vydat novou encykliku o vztahu člověka a prírody.

\section{Diskuse kolem povahy ekoetiky a pojmu TUR v rámci křest́anské etiky}

Diskuse ohledně křest'ansko-etických postojů k životnímu prostředí je již od doby vydání článku Lynna Whitea Historické kořeny naší ekologické krize (1967), který za základní přičinu ekologické krize považoval křest'anský antropocentrismus, velmi živá a stále se rozvíjí. Na výše nastíněném náčrtu vývoje oficiálních postojů katolické církve prezentovaných skrze SUC je patrné, že církev na podstatu kritiky, ale i na celkovou míru zvyšujícího se ekologického vědomí reaguje zásadním zpo̊sobem. Kromě tradice SUC je zde dále celý široký proud teologického a křest'ansko-etického myšlení, které dané otázky promýšlí v rozličných aspektech a kontextech. Od 60. let se jak v katolickém, tak v protestantském prostředí rozvíjí rozličné variace teologií stvoření, teologie hmoty, teologií rozvoje, z nichž mnohé nám ve stručnosti prezentuje Karel Skalický ve své knize Po cestách angažované teologie - Teologie křest́anské praxe. ${ }^{46}$ Některé jejich prvky sehrávají určitou roli v ekologicko-etické debatě a některé z nich mají poněkud radikálnější implikace přesahující výše naznačené intence SUC. Část z nich je dokonce natolik radikální, že jsou předmětem kontroverzí a nejsou považovány za součást „mainstreamové“ debaty pohybující se mezi póly umírněného antropocentrismu a ekocentrismu. ${ }^{47}$

Teologické myšlení s ekologickými akcenty poukazuje na možné biblické a teologické zdroje umírněně ekologického pohledu na svět, ovšem jak východiska, tak praktické implikace se do značné míry liší. Debata se pohybuje na škále od poměrně radikální křest'anstvím inspirované ekoetiky, která spolupracuje i s radikálnějšími ekologickými proudy a hnutími, až po poměrně konzervativní pohledy kritizující radikální ekologismus a inspirující se spíše tzv. „antiekologickými“" proudy. Př́ikladem první varianty je český evangelický teolog Erazim Kohák, člen čestné rady Hnutí Duha, předsednictva Společnosti pro trvale udržitelný život na Zemi, čestné rady hnutí Děti Země a člen ČSSD. Jeho velice známá a respektovaná kniha Zelená svatozárưt kromě prezentace zásadních názorových pohledů na ekologické otázky přináší i autorův pohled, který je kritický vůči některým formám ideologizace, aktivismu a romantického pojetí ekologie, ale zároveň jsou pro něj všechny proudy určitým způsobem inspirující - zdráhá se prezentovat př́liš jednoznačné a hotové odpovědi, ale volá zejména po „ekologické gramotnosti“ a skromném životním stylu. Jeho koncepci je možné taktéž chápat jako "teocentrickou“. ${ }^{49}$ Příkladem druhé varianty může být v našem kontextu poměrně známý americký neokonzervativní teolog Michael Novak, který je stoupencem tzv. „modrého environmentalismu“. Novak kritizuje „zelený environmentalismus“ pro jeho ekocentrismus, skeptické až apokalyptické vnímání reality, socialistické pojetí ekonomiky a obavy z přelidnění a vyčerpání

\footnotetext{
44 Evangelii gaudium, čl. 59.

45 Srov. kupříkladu článek Vztah člověka a přírody? Papež František píše biskupům list o ekologii / 2014/ (on-line), dostupné na: http:// goo.gl/Y5HyDF, citováno dne 21. 8. 2014.

46 Karel SKALICKÝ, Po cestách angažované teologie. Teologie křestanské praxe, Praha: Ježek, 2001.

47 Srov. kupříkladu poněkud panteizující koncepci Matthewa Foxe (Matthew FOX, Př́chod kosmického Krista: uzdravení Matky Země a počátek globální renesance, Brno: CDK, 2004) či dílo nekonformního morálního teologa Eugena Drewermanna (Eugen DREWERMANN, O nesmrtelnosti zvírat: naděje pro trpicí stvoření, Košice: Knižná dielňa Timotej, 1998).

48 Srov. Erazim KOHÁK, Zelená svatozár: kapitoly z ekologické etiky, Praha: Sociologické nakladatelství, 2000.

49 Srov. kupř́kladu jednu z nejnovějších Kohákových statí: Erazim KOHÁK, Bůh přírody, Bůh můj, in: Církev a společnost. Karlovi Skalickému k 80. narozeninám, eds. František ŠTĚCH - Roman MÍČKA, České Budějovice: TF JU, 2014, s. 281-288.
} 


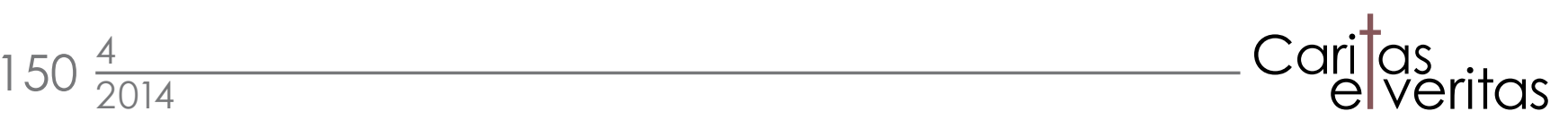

zdrojů. ${ }^{50}$ Za klíčové naopak považuje vymýcení světové chudoby prostřednictvím rozšiřování institucí kapitalismu, přičemž po vzoru amerického ekonoma Juliena Simona chová silnou důvěru v lidskou kreativitu a invenci - „nevyčerpatelný zdroj“. I když je debata velice široká a strukturovaná, přičemž nejde často jen o základní hodnotové představy (člověk a jeho hodnota, pozice v kontextu přírody apod.), ale i o povahu a formy případného řešení ekologických otázek (otázka priorit, možností regulací apod.), základním bodem sporu mezi křest'ansky orientovanou ekoetikou a jinými hodnotovými koncepcemi je otázka legitimity „křest'anského antropocentrismu“. V kontextu křest́anské antropologie je člověk vrcholem stvoření a jeho správcem, přičemž svou hodnotou a významem převyšuje svět přírody. Křest́anská etika, i když v posledních desetiletích výrazně docenila (možná do té doby zanedbaný) ekologický rozměr, stále trvá (více či méně) na antropocentrickém charakteru stvoření, přičemž právě SUC náleží svou povahou k oněm více antropocentrickým, za což bývá i náležitě kritizováno. Příkladem umírněné kritiky může být kupříkladu stat' Radima Kindla Environmentální analýza sociálních encyklik Jana Pavla II. ${ }^{51}$ I když Kindl vnímá ekologický rozměr SUC jako výtečný příspěvek do debaty ohledně ekologické krize, má kupř́ikladu za to, že Jan Pavel II. chápe stvoření přiliš antropocentricky a odvozuje "význam přírody z jejích účelů pro lidstvo jako celek“, 52 přičemž pomíjí, nebo jen slabě naznačuje hodnotu přírody o sobě samé, případně samotný „teocentrický“ rozměr stvoření. V závěrečném hodnocení Kindl uvádí, že i když „katolická církev zůstává i nadále v zajetí antropocentrismu“ a tento postoj dle jeho názoru "oslabuje snahu některých teologů o neantropocentrickou interpretaci křest'anské zvěsti a zužuje tak možnosti hledání adekvátního vztahu člověka a přírody v sociální nauce církve“", tak určitá shoda mezi papežovým pojetím rozvoje a koncepcí TUR vytváří prostor pro spolupráci environmentalistů a katolíků. ${ }^{53} \mathrm{Na}$ dvou př́kladech můžeme vidět, že Kindlovy pohledy jsou v některých aspektech radikální, když kupř́kladu lidskou práci považuje nikoli jako zušlecht'ující svět a dotvářející stvoření, ale výhradně jako devastující činnost zvyšující entropii v př́írodě. Dále považuje za nepřijatelný i papežův důraz na sexuální morálku a odmítání antikoncepce, které se podle něj pro mnoho zemí mohou "stát překážkou opravdového rozvoje“. ${ }^{54}$

Nicméně v duchu hledání konsensu i společných hodnotových východisek se čile rozvíjí debata ohledně konvergence a souladu mezi křest́ansky orientovanou ekoetikou a šířeji pojatým environmentalismem. Pokud se opět podíváme kupříkladu na reflexi pojmu TUR, můžeme mezi některými interprety SUC spatřovat úvahy o možném rozšiření či synchronizaci se sadou základních tradičně vypočítávaných principů SUC (personální princip, princip solidarity, princip subsidiarity, princip spravedlnosti, princip společného dobra) právě o princip TUR. Tuto myšlenku asi nejkomplexněji rozpracovává Markus Vogt ve své knize Prinzip Nachhaltigkeit: Ein Entwurf aus theologisch-ethischer Perspektive (2009), ${ }^{55}$ ovšem myšlenka je starší a předchází jí určitá debata v německojazyčném prostoru - př́íkladem jsou články autorů Helge Wulsdorfa a Thomase Schärtla Nachhaltigkeit: Vom Schlagwort zum Prinzip (2004) ${ }^{56}$ či obdobně laděné články již zmíněného Markuse Vogta, z nichž iniciační je pravděpodobně článek Das neue Sozialprinzip "Nachhaltigkeit" als Antwort auf die ökologische Herausforderung (1999). ${ }^{57}$ Autoři dospívají k závě-

50 Srov. Michael NOVAK, The Universal Hunger for Liberty. Why the Clash of Civilizations Is Not Inevitable, New York: Basic Books, 2004, s. 113-133.

51 Srov. Radim KINDL, Environmentální analýza sociálních encyklik Jana Pavla II., in: Petr FIALA - Jiří HANUŠ - Jan VYBíRAL eds., Katolická sociální nauka a současná věda, Brno: CDK, 2004, s. 171-189.

52 Tamtéž, s. 175.

53 Vše tamtéž, s. 187

54 Tamtéž, s. 184.

55 Markus VOGT, Prinzip Nachhaltigkeit: Ein Entwurf aus theologisch-ethischer Perspektive, München: Oekom Verlag, 2009.

56 Helge WULSDORF - Thomas SCHÄRTL, Nachhaltigkeit: Vom Schlagwort zum Prinzip, Ethica 12/2004 (2), s. 137-162.

57 Markus VOGT, Das neue Sozialprinzip „Nachhaltigkeit“ als Antwort auf die ökologische Herausforderung, in: Handbuch der Wirtschaftsethik, Gütersloh: Gütersloher Verlagshaus, 1999, s. 237-257. 
rům, že princip TUR je vlastně rozšiřrením principu spravedlnosti v rámci lidské společnosti na kontext mezigenerační, tedy vztahující se $\mathrm{k}$ budoucím pokolením lidstva, a dále i nad rámec vztahu člověka a společnosti směrem ke vztahu člověka a přírody, respektive celého stvoření. Američtí autoři Russell Butkus a Steven Kolmes v článku Ecology and the Common Good: Sustainability and Catholic Social Teaching (2007) ${ }^{58}$ zastávají obdobný pohled, ovšem váží princip TUR spíše na klasický princip společného dobra, který považují v SUC za určitým způsobem zastřešující ostatní principy. Společné dobro (lat. bonum commune) je definováno jako „souhrn podmínek společenského života, které jak skupinám, tak jednotlivým členům dovolují úplnější a snazší dosažení vlastní dokonalosti“ ${ }^{59}$ Podle autorů je stále zřejmější i ekologická dimenze tohoto principu, který jako předpoklad společenských podmínek předpokládá i závislost lidského druhu na životním prostředí a souvisí hluboce s dimenzí spravedlnosti. Celá tato debata však předcházela vydání encykliky Benedikta XVI. Caritas in veritate (2009), která pojem TUR, jak bylo referováno výše, v zásadě akceptuje a používá, i když nenabízí jednoznačnou definici či vyhlášení TUR jako specifického principu.

\section{Závěr}

Ekologická krize a poškozování životního prostředí jsou znamením času, na které SUC adekvátně reaguje a které reflektuje. V průběhu intenzifikace ekologického vědomí v zásadě SUC postupně přijalo koncept TUR v jeho základním významu mezigenerační solidarity a ohledů vưči př́írodě. Zasazuje jej však do širšího konceptu integrálního rozvoje člověka a lidstva, přičemž akcentuje antropologický rozměr ekologické otázky v kontextu biblické a teologické antropologie. Kromě ekologických a ekonomicko-rozvojových akcentů zdůrazňuje zásadně i rozměr důstojnosti člověka a jeho života od přirozeného počátku do přirozeného konce. Neztotožňuje se tak s radikálnějšími ekologickými koncepcemi, které mají ekocentrický či biocentrický charakter a jsou příliš skeptické vưči perspektivě dynamiky dalšího rozvoje, nebo naopak vůči potřebě omezení konzumismu.

Samotné SUC se v kontextu těchto debat může jevit jako jakási středová pozice vnímající důrazy a hodnoty obou pólů debaty ve snaze je vyváženě zohlednit. Nezastává skeptické, radikální a apokalyptické pozice a chová důvěru v člověka a jeho schopnost kreativně se rozvíjet v souladu s řádem stvoření při uspokojení svých základních životních potřeb, zároveň se nepřiklání k radikálním kritikům „ekologismu“ a nesouhlasí s ideou nelimitovaných možností rozvoje a konzumu. Díky svému etickému antropocentrismu však nemůže akceptovat ekocentrické či biocentrické pozice, které mnohdy chtějí řešit ekologickou otázku na úkor přiměřeného ekonomického rozvoje, svobodného tržního hospodářství či množstevní eliminace lidské populace. Proto bude SUC v trvalém sporu se snahami řešit ekologické otázky na úkor člověka, zachování jeho života a důstojnosti. Jeho důraz na kulturu života bude stát v trvalé opozici vůči novým a mocným nástrojům „kultury smrti“, které se mnohdy zaobalují do líbivého hávu ekologických důrazů. Zároveň však může svým akcentem na revizi životních způsobů a uměřenost konzumu výrazně přispět ke kultivaci udržitelného integrálnúho rozvoje lidstva a přírodního prostředí. Asi nejlépe jsou „antropocentrické“ postoje SUC definovány v dosud nezmiňovaném Kompendiu sociální nauky církve (2004), které představuje systematizovaný a komplexní přehled SUC a v němž jsou místy interpretovány a komentovány klasické sociální encykliky i další texty:

58 (c) Russell BUTKUS - Steven KOLMES, Ecology and the Common Good: Sustainability and Catholic Social Teaching, Journal of Catholic Social Thought 4/2, 2007, s. 403-436 (on-line), dostupné na: http:/ / goo.gl/KXzN5d, citováno dne 21. 8. 2014.

59 Gaudium et spes, čl. 26. 
„Správné pojetí životního prostředí na jedné straně nemůže utilitaristicky redukovat př́rodu na pouhý předmět manipulace a využívání, na straně druhé však také nesmí přírodu absolutizovat a nadřazovat ji důstojnosti lidské osoby. $V$ tomto druhém případě se dospívá až ke zbožšt'ování přírody nebo země, jak je to patrné u některých ekologických hnutí, která se snaží získat pro své pojetí mezinárodně zaručený institucionální status. Učitelský úřad církve odůvodnil svůj odmítavý postoj vůči ekocentrickému a biocentrickému pojetí životního prostředí tím, že toto pojetí chce eliminovat ontologický a axiologický rozdíl mezi člověkem a ostatními živými bytostmi..."60

V otázce antropocentrického důrazu je SUC poněkud konzervativnější než pohledy a názory některých křest'ansky orientovaných ekologických etiků a teologů, kteří naopak zdůrazňují teocentrický charakter Božího stvoření. Zde je však možno na částečné obhájení SUC uvést, že přes nespornou přítomnost teocentrického rozměru je SUC primárně orientováno na vztah člověka a společenských institucí, nikoli na teologii stvoření a reflexi ontologické hodnoty přírody. Dynamicky se rozvíjející teologické příspěvky v oblasti teologie stvoření tak možná budou zhodnoceny a kriticky recipovány v plánované a avizované encyklice papeže Františka o vztahu člověka a přírody, čímž se doplní celkový integrální obraz vztahu mezi Bohem, stvořením a člověkem.

\section{Princip trvale udržitelného rozvoje v sociálním učení církve}

Abstrakł Článek předkládá kontext a rozvoj pojmu trvale udržitelného rozvoje a klade si otázku, nakolik je uplatněn a reflektován v sociálním učení církve a v širším kontextu křestanské etiky. Sleduje vývoj pojmu $\checkmark$ průběhu tří konferencí OSN věnovaných životnímu prostředí (Stockholm, Rio de Janeiro, Johannesburg) i v následné odborné a ideologické debatě ohledně obsahu a dưsledkủ daného pojmu. Dále je zkoumáno téma rozvoje a udržitelného rozvoje $v$ dokumentech sociálního učení katolické církve i v křestanském sociálně-etickém myšlení, jeho postupná recepce i odlišnosti vưči jeho obecnému užití. $\vee$ průběhu intenzifikace ekologického vědomí v zásadě sociální učení církve postupně prǐijalo koncept trvale udržitelného rozvoje $v$ jeho základním významu mezigenerační solidarity a ohledů vưči prírodě. Zasazuje jej však do širšího konceptu integrálního rozvoje člověka a lidstva a akcentuje antropologický rozměr ekologické otázky v kontextu biblické a teologické antropologie. Kromě ekologických a ekonomicko-rozvojových akcentů zdưrazňuje zásadně i rozměr důstojnosti člověka a jeho života od prirozeného počátku do přirozeného konce. Neztotožňuje se tak s radikálnějšími ekologickými koncepcemi, které maji ekocentrický či biocentrický charakter a jsou přliš skeptické vưči perspektivě dynamiky dalšího rozvoje, nebo naopak vưči potřebě omezení konzumismu. Dưraz sociálního učení církve na kulturu života bude stát v trvalé opozici vưči novým a mocným nástrojům „,kultury smrti“, které se mnohdy zaobalují do líbivého hávu ekologických dưrazů. Současně může svým akcentem na revizi životních zpưsobů a umírněnost konzumu výrazně přispět ke kultivaci udržitelného integrálního rozvoje lidstva a přirodního prostředí.

Klíčová slova rozvoj; trvale udržitelný rozvoj; ekologie; globalizace; sociální učení církve; sociální encykliky; křestanská sociální etika; etický antropocentrismus; ekoetika; konzumismus

\section{The Principle of Sustainable Development in Catholic Social Teaching}

Abstract The paper presents the context and development of the concept of sustainable development and asks to what extent it is applied and reflected in Catholic social teaching and the broader context

60 Kompendium sociální nauky církve (2004), čl. 463. 
of Christian ethics. It follows the development of the concept in the course of three UN conferences devoted to the environment (Stockholm, Rio de Janeiro, Johannesburg) as well as in the subsequent expert and ideological debate concerning the content and implications of the concept. It further examines the topic of development and sustainable development in the documents of the social teaching of the Catholic Church and in Christian social-ethical thought, its gradual reception and differences from its general use. In the process of intensification of ecological consciousness Catholic social teaching gradually received the concept of sustainable development in its basic meaning of intergenerational solidarity and respect to nature. However, it sets it in the broader concept of integral human development and underlines the anthropological dimension of ecological issues in the context of biblical and theological anthropology. Besides ecological and economic-developmental accents it fundamentally stresses the dimension of human dignity and life from natural beginning to natural end. Thus it does not identify with the more radical ecological conceptions, which are ecocentric or biocentric in character and are overly sceptical to the perspective of the dynamics of further development, or conversely to the need to limit consumerism. Its emphasis on culture of life will be in permanent opposition to new and powerful instruments of the "culture of death", which often shroud in the agreeable garment of ecological emphases. With its accent on revising lifestyles and moderating consumption it can markedly contribute to cultivating sustainable integral development of humanity and the natural environment.

Keywords development; sustainable development; ecology; globalization; Catholic social teaching; social encyclicals; Christian social ethics; ethical anthropocentrism; ecoethics; consumerism 